\title{
The surprising place of cognitive psychology in the work of F.A. Hayek
}

Citation for published version (APA):

Birner, J. (1995). The surprising place of cognitive psychology in the work of F.A. Hayek. METEOR, Maastricht University School of Business and Economics. METEOR Research Memorandum No. 019 https://doi.org/10.26481/umamet.1995019

Document status and date:

Published: 01/01/1995

DOI:

10.26481/umamet.1995019

Document Version:

Publisher's PDF, also known as Version of record

\section{Please check the document version of this publication:}

- A submitted manuscript is the version of the article upon submission and before peer-review. There can be important differences between the submitted version and the official published version of record.

People interested in the research are advised to contact the author for the final version of the publication, or visit the DOI to the publisher's website.

- The final author version and the galley proof are versions of the publication after peer review.

- The final published version features the final layout of the paper including the volume, issue and page numbers.

Link to publication

\footnotetext{
General rights rights.

- You may freely distribute the URL identifying the publication in the public portal. please follow below link for the End User Agreement:

www.umlib.nl/taverne-license

Take down policy

If you believe that this document breaches copyright please contact us at:

repository@maastrichtuniversity.nl

providing details and we will investigate your claim.
}

Copyright and moral rights for the publications made accessible in the public portal are retained by the authors and/or other copyright owners and it is a condition of accessing publications that users recognise and abide by the legal requirements associated with these

- Users may download and print one copy of any publication from the public portal for the purpose of private study or research.

- You may not further distribute the material or use it for any profit-making activity or commercial gain

If the publication is distributed under the terms of Article $25 \mathrm{fa}$ of the Dutch Copyright Act, indicated by the "Taverne" license above, 


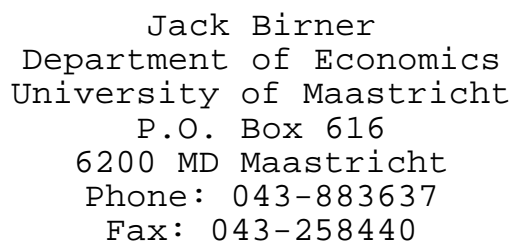

e-mail: j.birner@algec.rulimburg.nl

\begin{abstract}
In 1920, when Hayek was a student, he wrote a manuscript on cognitive psychology, which was published in 1952 as the Sensory order. From the 1920s to the early 1940s Hayek developed his business cycle theory. The perceptions of economic agents play a central part in this theory. Contrary to what one might expect, however, none of the mental mechanisms of his earlier theory on perception and cognition play a part in his economics. The answer to this apparent anomaly lies in the programmatic character of the whole of Hayek's work, and in the specific way in which his ideas evolved. His psychology played a prominent role in the later development of his ideas. If Hayek's psychology influenced his early economics, it did so indirectly, by shaping his methodology. However, there may also be a common influence underlying both Hayek's psychology and his economic methodology.
\end{abstract}




\author{
The surprising place of \\ cognitive psychology \\ in the work of \\ F.A. Hayek
}

Jack Birner

University of Maastricht

\begin{abstract}
Introduction
It is not too far-fetched to speak of two recent revolutions in economics, and in social science in general: the cognitive revolution, and the evolutionary revolution. However, so far these have, for all intents and purposes, remained separate. In the work of F.A. Hayek (1899-1992) the two are intimately connected. One of the earliest interests of Hayek was indeed in cognitive psychology. In 1920, at the age of 21, he wrote a manuscript that contained the theory of cognitive psychology, which was published in 1952, in an extended version, as The Sensory order (SO). In the mean time Hayek had chosen an entirely different career. He had become an economist. Between 1928 and 1941 he developed his theory of the business cycle and the underlying theory of capital. In Hayek's explanation of cyclical fluctuations in economic activity relies on the distinction between real relative scarcities on the one hand, and on the other hand the perception that individual decision makers have of relative prices. One of Hayek's earliest criticisms of the standard explanation of business cycles was that they made use of the concept of the general price level. Hayek's criticism was that this is a statistical construct which could not, by its very nature, be perceived by individual decision makers. The idea that the perceptions of individuals have to be taken into account in explanations in social science is called subjectivism. The explanation of perception and cognition is the objective of Hayek's psychology, which he had already developed before he became an economist. The curious thing is that Hayek did not refer cognitive psychology, his own or anyone else's, in his business cycle theory. None of the mental mechanisms of his earlier theory on perception and cognition play a part in his economics. It was not until Hayek's contribution to the debate on socialism, in 1935, that cognitive arguments started to play a role in his published work. Knowledge, and more in particular its division and co-ordination, was not addressed as a problem in its own right until 1937, when "Economics and Knowledge" was published. And it was only in his work on the philosophy of science of the 1950s and later, and on social philosophy of the 1960s, i70s and '80s that explicit references to some central concepts of Hayek's cognitive psycholoy can be found. Why did Hayek not incorporate his ideas on cognitive psychology in his economics, and why did it take so long for these ideas to emerge in the rest of his work?
\end{abstract}

\title{
Hayek's cognitive psychology
}

The manucript "Beiträge zur Theorie der Entwicklung des Bewusstseins" (Contributions to the theory of the development of consciousness) which Hayek wrote as a young man of 21 contains in essentials the same theory as The Sensory Order, which was published in 1952. Therefore I shall quote from the book when discussing Hayek's cognitive psychology.

Hayek assumes that there are two "orders" in which the human mind arranges the objects in the world: the physical order, which classifies events as similar or different according to whether they produce similar or different other external events; and the sensory order, which classifies events according to their sensory properties. In contrast to Ernst Mach, Hayek holds that there is no simple one-to-one correspondence between the elements of the two orders. Indeed, this criticism of Mach was the reason why Hayek wrote the manuscript on cognitive psychology ( $\mathrm{cp}$. De Vries 1994). Events which appear to our senses to be of the same kind may be different in the physical order, and the other way around. The relation between the sensory order of the human mind (or the "microcosm") and the physical order of external events (or "macrocosm"; SO, p. 4) is the central problem of so.

The human mind works through a continuous process of classification and reclassification of sense impressions and the classifications formed from 
them. This process is located in the "neural order" of the central nervous system, which is part of the physical order. The mind is continuously involved in a process of self-organization which consists of an evolutionary process that leads to an ever more complex set of classifications. The mind functions through this process of evolution.

An evolutionary framework is part and parcel of Hayek's psychology. The evolution of the human mind is part of the evolutionary process in which organisms, in this case man, struggle to survive:

"Our task is (..) to show in what sense it is possible that within parts of the macrocosm a microscosm may be formed wich reproduces certain aspects of the macrocosm and through this will enable the substructure of which it forms part to behave in a manner which will assist its continued existence." (SO, 5.78)

One of the central theses of the book, and one of the great differences with the psychology of Mach, is that

"the sensory (or other mental) qualities are not in some manner originally attached to, or an original attribute of, the individual physiological impulses, but that the whole of these qualities is determined by the system of connexions by which the impulses can be transmitted from neuron to neuron; that it is thus the position of the individual impulses or group of impulses in the whole system of such connexions which gives it its distinct quality; that this system of connexions is acquired in the course of the development of the species and the individual by a kind of 'experience' or 'learning'; and that it repoduces therefore at every stage of its development certain relationships existing in the physical environment between the stimuli evoking the impulses." (SO, 2.49)

Thus, there are no pure sense data or facts, but all facts are embedded in a complex of relations to other facts, which we may call, in the terminology of so, a "map". From this map, which serves as a kind of first approximation, more permanent sets of classifications is formed. Hayek calls these "models".

"It is (..) the process of multiple classification which builds the model. What we have before called the "map", the semi-permanent apparatus of classification, provides the different generic elements from which the models of particular situations are built. The term "map", which suggests a sort of schematic picture of the environment is thus really somewhat misleading. What the apparatus of classification provides is more a sort of inventory of the kind of things of which the world is built up, a theory of how the world works rather than a picture of it. It would be better described as a construction set from which the models of particular situations are built." (SO, 5.89)

These models are not complete representations of the world. That it is possible for the mind to build representations of the physical order from a set of models that is necessarily limited, is due to the accidental fact that the structure of the world is "redundant", to use Herbert Simon's term: ${ }^{1}$

"It is (...) no more than a fortunate accident that the different events in the macrocosm are not fully interrelated to any significant degree, but that as a rule it is possible to base predictions of certain kinds of events on a mere selection of a totality of events." $(\mathrm{SO}, 5.90)$

And even though Hayek thinks that the microcosm of the mind is capable of reproducing the structure of the macrocosm of the physical order (cp. SO, 5 . 78, quoted above), "there will clearly exist definite limits to which such a microcosm can contain an adequate reproduction of the significant factors in the macrocosm." (SO, 5.90).

Cp. Simon 1968 . 
Hayek's research programme in economics

Now that I have given a brief impression of some of the main features of Hayek's cognitive psycholoy, I want to summarize his economics. From his earliest publications in economics, Hayek himself explicitly and repeatedly states the problems he intends to solve, the solutions that have been attempted sofar, the methodological constraints that successful solutions have to satisfy, and the direction his own future research is to take. ${ }^{2}$ Hayek's ideas on economics show clear signs of development, and he developed his economics systematically to such an extent that one may speak of a research programme. In general, research programmes (RPs) are defined by problems and methodological principles. Philosophers of science have used these elements very fruitfully when reconstructing episodes of intellectual history. I shall follow their example for presenting Hayek's economics.

A useful instrument for reconstructing the development of Hayek's economic theory is the following scheme of Karl Popper's. ${ }^{3}$

$$
\mathrm{P}_{1} \rightarrow \mathrm{T}_{1} \rightarrow \mathrm{EE} \rightarrow \mathrm{P}_{2} \text { etc. }
$$

Theories $\left(\mathrm{T}_{i}\right)$ are formulated as solutions to problems $\left(\mathrm{P}_{i}\right)$. The adequacy of the solutions is examined in a process error elimination (EE), which usually gives rise to new problems. In what follows I will simplify the scheme to a sequence of problems and theories and omit explicit mention of error elimination, as this would get us too deeply involved in technical details. Hayek's RP in economics may be summarized as follows. The global problem (or original problem situation) that defines the outlines of the programme is how to explain fluctuations in the level of production and employment, a dynamic disequilibrium phenomenon, by means of general equilibrium theory. Therefore, either the business cycle has to be modelled in a way that makes it amenable to analysis in terms of static general equilibrium theory, or general equilibrium theory has to be dynamized. ${ }^{4}$ From this global problem setting derive a number of more specific problems of a technical economic nature.

Hayek's recurrent statements of his RP in economics are interspersed with methodological comments. Geldtheorie und Kunjunkturtheorie (or Monetary Theory and the Trade Cycle) devotes an entire chapter to methodology, and the first chapter of prices and Production is explicitly methodological in its diagnosis of the stagnation in the development of business cycle theory. It is due to the fact that economists have adopted the wrong method. Irving Fisher's revival of the mechanistic form of the quantity theory in particular stands accused of having led to "the present isolation of the theory of money from the main body of general economic theory" ( $\mathrm{p}$. 4), because of the use of "different methods for the explanation of values as they are supposed to exist irrespective of any influence of money, and for the explanation of that influence of money on prices (...)" ( $p .4)$. Because that is what economists do when they

"try to establish direct causal connections between the total quantity of money, the general level of all prices and, perhaps, also the total amount of production. For none of these magnitudes as such ever exerts an influence on the decision of individuals; yet it is on the assumption of a knowledge of the decisions of individuals that we owe whatever understanding of economic phenomena that we possess; that the modern "subjective" theory has advanced beyond the classical school in its consistent use is probably its main advantage over their teaching."

2 There is no room here for an exhaustive list of such statements. The most complete statement of the RP can be found in Hayek 1933. But cp. for instance also Hayek 1924, in particular pp. 367, 370, and 378-9; Hayek 1925, pp. 17, 20 and 25; and Hayek 1927, pp. 68-9, n. 12 .

${ }^{3}$ Cp., for instance, Popper 1976, ch. 29. The programmatic character of Hayek's economics is analyzed in much more detail in Birner (forthcoming).

${ }^{4}$ For a general description of the adaptation of models to an idealized theory, cp. Bunge 1973. 
(ibid.)

Hayek firmly puts methodological individualism (MI) forward as the method of economic analysis:

"[F]rom the very nature of economic theory, averages can never form a link in its reasoning; but to prove this contention would go far beyond the subject of these lectures. I shall here confine myself to an attempt to show in a special field the differences between explanations which do and explanations which do not have recourse to such concepts." (p. 5)

Notice the near-promise of an elaboration into a methodological RP, a promise that may be considered to be truly programmatic in view of the fact that it was fulfilled later. ${ }^{5}$ The impression that prices and Production is an exercise in the application of a particular method, and not just an economic theory, is reinforced by the remark: "it is the method of approach more than the details of the results which is of importance in what follows." (p. 31) By 1931, Hayek's RP in economics had turned into a methodological programme as well.

The methodological principles that guide the development of Hayek's RP in economics are:

(1) Theoretical unification, the principle that all economic phenomena should be explained in terms of a single theory. This is linked with the use of a highly idealized theory which is far removed from empirical reality. In order to re-establish contact with empirical reality the idealized explanations are supplemented with

(2) the method of decreasing abstraction.

(3) MI, which for Hayek's economics amounts to reducing all explanations of the business cycle to marginal value theory.

(4) Subjectivism, the principle that all explanations should run in terms of what individuals perceive.

Hayek's RP may now be reconstructed as follows. Its theoretical background is static general equilibrium theory. In order for a static theory of equilibrium conditions to explain an inherently dynamic disequilibrium phenomenon such as the business cycle, two problems have to be solved. One is the incorporation of time, the other the introduction of a factor or mechanism that causes the disturbances of equilibrium. These two basic or global problems give rise to two sub-programmes.

5 In the publications that were collected in The Counterrevolution of Science, Hayek 1955 
$\mathrm{P}_{1}$ : how is time to be incorporated?

$\mathrm{T}_{1}$ : generalised, diachronic (or intertemporal) general equilibrium theory

$\mathrm{P}_{2}$ : in reality there are hardly any diachronic prices and futures markets

$\mathrm{T}_{2}$ : theory of the production structure

$\mathrm{P}_{3}$ : how is the production structure adapted?
$\mathrm{P}_{1}{ }_{1}$ : how do disequilibria arise?

$\mathrm{T}_{2}{ }^{\prime}$ : theory about perceived prices

$\mathrm{P}_{2}^{\prime}$ : what gives rise to wrong perceptions?

$\mathrm{T}_{2}^{\prime}$ : monetary theory

\section{$\mathrm{T}_{3}$ : trade cycle theory}

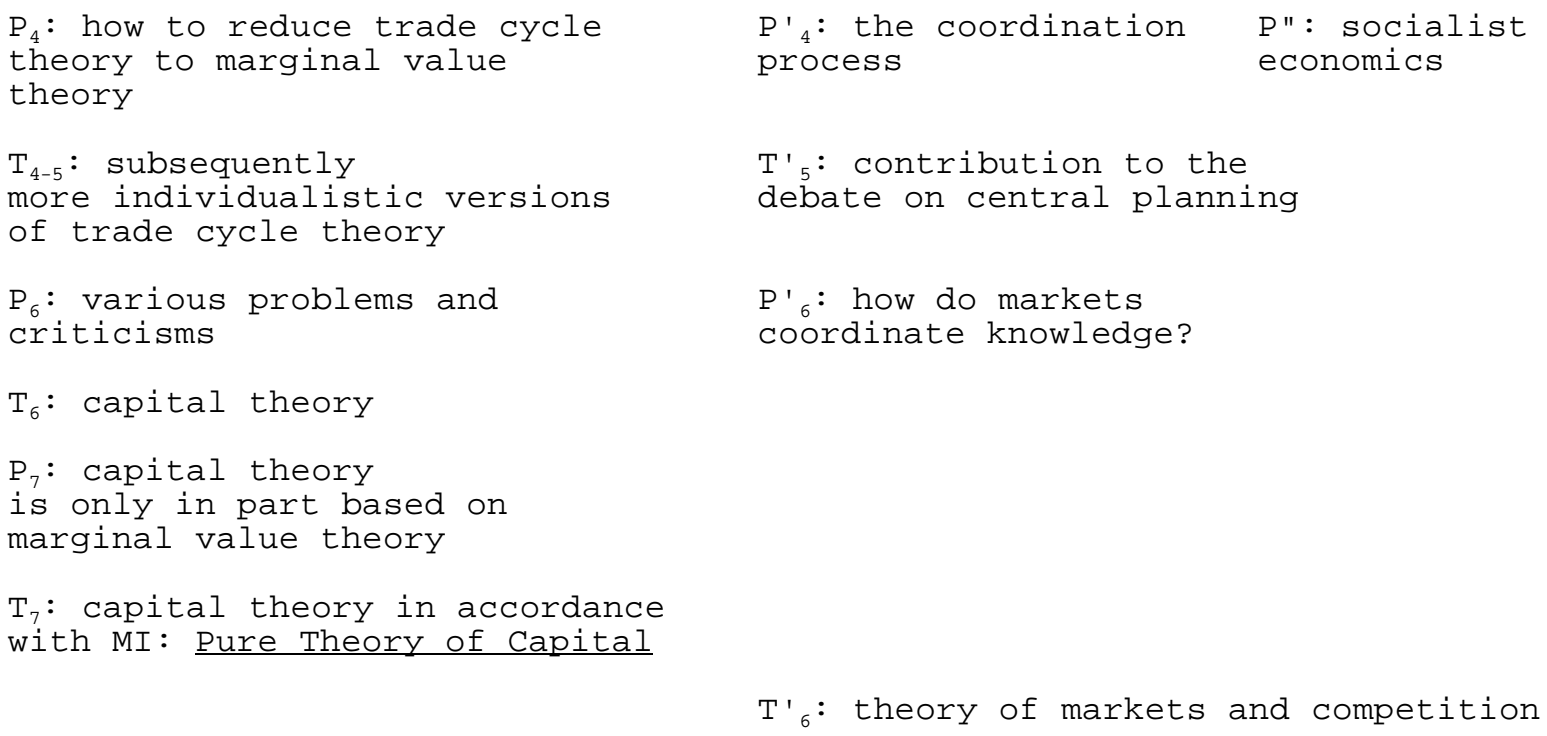


The scheme is meant to capture the chronology of Hayek's RP in economics, but it is stylized. Thus, ever since Prices and Production Hayek worked on the perfection of his capital theory, and elements of such a theory on an MI foundation can already be found before pure Theory of Capital (PTC) was published. There are two branches or sub-programmes in Hayek's RP in economics:

1. An individualist programme. It is defined by the problem how all economic theories, and in Hayek's case especially the theory of the business cycle, are to be reduced to the individualistic theory of marginal value (or the pure logic of choice as Hayek called it). The working out of this reductionist programme kept Hayek occupied for most of the 1930s. It involved finding solutions to mainly technical problems in capital theory.

2. A subjectivist programme. Hayek attached great importance to the way in which and the medium through which individuals perceive their economic environment. This is quite clear from his early writings in economics. He is opposed to the use of aggregates in economic theory because they are not the sort of things which individuals perceive. Hayek derived his inspiration for the distinction between perceived as opposed to real magnitudes from the economics of Wicksell and Mises. There is no evidence in his early work in economics that Hayek used his own theory of cognitive psychology.

"Economics and Knowledge" of 1937 forms a link between the two branches of his RP. The article addresses the methodological question of the empirical content of economic theory. The answer is given by a description of the logical structure of economic theory. Its core is the pure logic of choice, which is tautologous, and the empirical content resides in the propositions surrounding the core which describe "how knowledge is acquired and communicated" (Hayek 1937: 33). In the light of Hayek's earlier psychology, this statement would justify the expectation that Hayek would apply that theory to the problem in hand. But he does no such thing. Instead, he confesses that he has made no progress in finding the "concrete hypotheses concerning the condtions under which people are supposed to acquire the relevant knowledge and the process by which they are supposed to acquire it." (Hayek 1937: 48). Even though the acquisition of knowledge is now explicitly introduced in the sphere of economics for the first time, the acquisition process is not described in cognitive-psychological terms. Rather, the 1937 article is a methodological progress report in which Hayek summarizes the state of affairs in the reductionist branch of his RP. What he observes about the coordination of dispersed knowledge is inspired by the socialism debate, and it sketches the further development of the subjectivist branch of the RP, which had remained in a rather rudimentary state during the first half of the $1930 \mathrm{~s}$.

Why?

By the time Hayek could have paid more attention to the subjectivist branch of his RP, given the progress he made in the other branch (the systematic writing up and elaboration had already progressed and was published in 1941 in PTC), his interests had shifted from the perception and formation of expectations by individual agents to the distribution and co-ordination of knowledge. This shift in emphasis took place, in all likelihood, under the influence of his contribution to the debate on socialism. Some, such as Caldwell, speak of a break in Hayek's work, meaning that he abandoned equilibrium theory. This is not correct (cp. my arguments in Colonna, Hagemann \& Hamouda 1995). Hayek did not see any discontinuity in the development of his own thought. He does indicate that he has moved from an emphasis on the knowledge that economic agents have of their immediate environment, or their perception of their situation, to another knowledge-related problem, which is how the individual bits and pieces of knowledge can be co-ordinated. In his theory of the business cycle the perception by economic agents of their local situation is the central explanatory feature. In the socialism debate it is the impossibility of collecting and processing the local knowledge of individuals. Indeed, Hayek later discusses both, plus a third position, as variants of subjectivism (cp. Hayek 1955, ch. III):

$\left(s_{1}\right)$ The facts of the social sciences are the opinions of the actors.

$\left(\mathrm{s}_{2}\right)$ Heterogeneous knowledge which is present in a dispersed form and has to be coordinated.

$\left(\mathrm{s}_{3}\right)$ Social scientists can explain the behaviour of other people because their minds classify external stimuli according to the same principles as the minds of their objects of study. 
The emphasis on the way in which individuals perceive economic reality ( $\left.s_{1}\right)$ was present from Hayek's earliest writings on in his theory of the monetary system. Individuals perceive money prices, and these are the data of individual plans. The discrepancy between this informational input and real relative scarcities causes coordination failures. With Hayek's largely methodological 1937 article as a catalyst, this subjectivist sub-programme was generalized to explain the process of coordination between individual plans $\left(s_{2}\right)$. Finally, $s_{3}$ reflects the influence of so (remember that the threefold distinction in ch. III of Hayek 1955 dates back to 1941; so this would be an indication that Hayek resumed his work on SO as early as 1941).

The explanation of Hayek's neglect of his own cognitive psychology in his business cycle theory, and his later neglect of cognitive psychology when discusing economic co-ordination problems, may be stated with some exaggeration as follows:

When Hayek had still enough interest in the role of the individual agent, he was too busy with the solving of technical problems. And when he had made proress with these technical problems, his inerest had shifted from the role of the individual agent to the social process of co-ordinating the individual agents' knowledge and actions. Thus, an opportunity was missed to make progress with the explanation of how expectations are formed and how individuals learn. Social learning was substituted for individual learning.

In sofar as Hayek still had the explanation on his research agenda of the way in which individuals perceive their environment and form expectations, he was discouraged from going ahead with this by an external event. By the time Hayek had dealt with the technical problems of the reductionist programme of MI in capital theory, Keynes had captured the entire audience of economists. They lost interest in Hayek's economics. That was one of the reasons why he diverted his research to the more general questions dealing with the stability of society as a whole (cp. Hayek 1978: 219). But this did not constitute a break in Hayek's work, for the momentum for this relatively new area was provided by the work he had already done in the field of economic coordination problems. Hayek generalized certain themes of his RP in economics into an analysis of the evolution and functioning of social institutions (cp. Birner 1994: 6).

"Individualism True and False" of 1945 (ITF) is a milestone in the generalization of Hayek's thought from the domain of economics to that of social theory. The emphasis of "Economics and Knowledge" was predominantly on methodology, and problems of economic theory were discussed only in a derivative way. In ITF it is just the other way around. As is usual in all of Hayek's work, methodology does play a role, but in ITF he works out the consequences a particular theory of society. The related methodology in question is the individualism of the Scottish Enlightenment. But like the political theory that values the freedom of the individual, this methodology is secondary. The "individualism [of the scottish philosophers] ... is primarily a theory of society, an attempt to understand the forces which determine the life of man, and only in the second instance a set of political maxims derived from this view of society." (p. 6) The article bears the traces of Hayek's previous work in other domains. Thus, his contribution to the socialism debate of the 1930s shines through when Hayek observes that "Carl Menger, who was among the first in modern times consciously to revive the methodical individualism of Adam Smith and his school, was probably also the first to point out the connection between the design theory of social institutions and socialism." (p. 4, n. 3). And the influence of his work on general equilibrium theory, planning and particularly the role of expectations can be read into the passage where Hayek observes about the individualism of the scots that "its basic contention is (...) that there is no other way toward an understanding of social phenomena but through our understanding of individual actions directed toward other people and guided by their expected behavior. (p. 6; emphasis added). The general argument of ITF is an elaboration of one of the constants that characterize Hayek's work in economics from the very first moment: his criticism of aggregates. This criticism has now been generalized to a criticism of holism or collectivism:

"This argument [of the Scottish philosophers] is directed against the properly collectivist theories of society which pretend to be able 
directly to comprehend social wholes like society, etc., as entities sui generis which exist independently of the individuals which compose them. The next step in the individualistic analysis of society (..) is the contention that, by tracing the combined effects of individual actions, we discover that many of the institutions on which human achievements rest have arisen and are functioning without a designing and directing mind (...) and that the spontaneous collaboration of free men often creates things which are greater than their individual minds can ever fully comprehend." (pp. 6-7)

This has to be distinguished from the so-called individualism of the Cartesian school, which is usually referred to as rationalism. This is why Hayek calls the true individualism of the Scottish Enlightenment anti-rationalism.

"The antirationalistic approach, which regards man not as a highly rational and intelligent but as a very irrational and fallible being, whose individual errors are corrected only in the course of a social process, and which aims to make the best of a very imperfect material, is probably the most characteristic feature of English individualism." (pp. $8-9)^{6}$

This insight is due to Mandeville. The main differences between the pseudoindividualism of the rationalistic or engineering on the one hand and the true individualism of the scots are the following:

1. "true individualism is the only theory which can claim to make the formation of spontaneous social products intelligible." (p. 10)

2. "true individualism believes on the contrary that, if left free, men will often achieve more than individual human reason could design or foresee." (pp. 10-11)

This has its ramifications in politics: "the main merit of the individualism which he [Smith] and his contemporaries advocated is that it is a system under which bad men can do least harm." ( $p$. 11). However, true individualism is a theory of society as a whole.

"The great concern of the great individualist writers was indeed to find a set of institutions by which man could be induced, by his own choice and from the motives which determined his ordinary conduct, to contribute as much as possible to the need of all others (...)" (pp. 12-13)

Underlying this theory of society is

"a view which in general rates rather low the place which reason plays in human affairs, which contends that man has achieved what he has in spite of the fact that he is only partly guided by reason, and that his individual reason is very limited and imperfect... One might even say that the former is the product of an acute consciousness of the limitations of the individual mind which induces an attitude of humility toward the impersonal and anonymous social process by which individuals help to create things greater than they know..." (p. 8)

The great discovery of the classical economists is that "many of the institutions on which human achievements rest have arisen and are functioning without a designing and directing mind (...) and that the spontaneous collaboration of free men often creates things which are greater than their individual minds can ever fully comprehend." (p. 7)

When we reconstruct Hayek's transition from economics to the wider domain of the theory of society as a whole, we may observe that two intermediary steps are involved. One is the variant of subjectivism that states "the constitutional limitation of man's knowledge and interests, the fact that he cannot know more than a tiny part of the whole of society and that therefore all that can enter into his motives are the immediate effects which his actions will have in the sphere he knows." (ITF: 14)

6 This is very similar to Popper's approach to social science. Watkins has coined the fortunate term "negative utilitarianism" for this. 
The other step is the conception of social institutions as problem-solving mechanisms. The problem they solve is one that Hayek came to address explicitly and in general terms in his philosophy of science of the late 1950s and early 1960s, viz. the problem of complexity. It has struck Hayek, following the philosophers of the Scottish Enlightenment, that institutions are capable of performing tasks that are far too complex for individual human minds. In a less general form the problem of complexity is addressed already in Hayek's "Economics and Knowledge" of 1937 and "The Use of Knowledge in Society" of 1945, which deal with the problem of coordination.

All these elements together lead to an explanation of social institutions as undesigned, spontaneously grown mechanisms that by discovering and coordinating dispersed knowledge reduce the complexity facing indviduals with limited knowledge and thus allow their actions to be coordinated. So Hayek's transition from his economic $R P$ to the field of social and political philosophy is the result of the application of the same methodological principles that defined his economic RP to different problems. Or rather to a problem situation that arose out of a generalization of the economic problem that defined the second branch of the economic RP, the problem of coordination. That the transition of Hayek to social philosophy involves a generalization of his ideas on economics, is confirmed by what Hayek says in ITF: "What the economists understood for the first time was that the market as it had grown up was an effective way of making man take part in a process more complex and extended than he could comprehend and that it was through the market that he was made to contribute to "ends which were no part of his purpose."" (pp. 14-5). Hayek explicitly acknowledges that the economists had found a theory of social learning, one which had been implicit in his own theory of the business cycle and capital theory all the time. The revelation for Hayek himself that economics is about social learning finds its first tentative formulation in his 1937, while the issue is just below the surface of the arguments in the planning debate. The belief in a theory social learning is consistent with a social theory of rationality. And indeed, Hayek does take the step from individual rationality to social rationality:

"The true basis of [the individualist's] argument is that nobody can know who knows best and that the only way by which we an find out is through a social process in which everybody is allowed to try and see what he can do. The fundamental assumption, here as elsewhere, is the unlimited variety of human gifts and skills and the consequent ignorance of any single individual of most of what is known to all the others members of society taken together. Or, to put this fundamental contention differently, human Reason, with a capital $R$, does not exist in the singular, as given or available to any particular person, as the rationalist approach seems to assume, but must be conceived as an interpersonal process in which anyone's contribution is tested and corrected by others." (ITF: 15)

For the social character of rationality, cp. also Hayek 1965, "Kinds of Rationalism", p. 93: the "desire to make everything subject to rational control, far from achieving the maximal use of reason, is rather an abuse of reason based on a misconception of its powers, and in the end leads to a destruction of that free interplay of many minds on which the growth of reason nourishes itself." (added). Reason (with a capital R) is just as much an emergent property of interactions between individual agents within a social system as knowledge is an emergent property of the interaction between individual neurons within the system of connections that constites the human mind. ITF contains so many elements from Hayek's cognitive psychology that it seems to justify the hypothesis that when Hayek wrote ITF, he was already working on the book that was to be published as Sensory Order. This raises the question: did Hayek see society as a mind-like organism? Before answering this, let us look more closely at the connections between so and Hayek's theory of society.

The epistemic turn in Hayek's thought: cognitive psychology as a source of ideas on social science and society

For understanding the role of so in the development of Hayek's theory of society the following two general connections are helpful: 
1. In Hayek's work, the theme of communication is a crucial intermediate step between his economics and his later theory of society as a whole: "Economics and Knowledge" of 1937, with a later follow-up in "The Use of Knowledge in Society" of 1945, and "Competition as a Discovery Procedure" of 1968. Already in his contributions to the socialism debate communication is an important element. Communication takes place through the price system. Communication failures are the causes of business cycles, and they are caused by distortions of relative prices because of changes in the money supply. In a very real sense, the response of an economy to these communication failures constitutes a process of social learning. At any rate, communication and learning are closely connected in Hayek's work.

2. During all of his active intellectual life, Hayek was looking for solutions to the problem of explaining collective effects from individualist premises. His work on so made him see the role of collective effects, and more in particular social institutions, in a new light. Thus, he says in "Kinds of Rationalism" (1965 pp. 91-2):

"When I look back, it seems all to have begun, nearly thirty years ago, with an essay on "Economics and Knowledge" in which I examined what seemed to me some of the central difficulties of pure economic theory. Its main conclusion was that the task of economic theory was to explain how an overall order of economic activity was achieved which utilized a large amount of knowledge which was not concentrated in one mind but existed only as the separate knowledge of thousands or millions of different individuals. But it was still a long way from this to an adequate insight into the relations between the abstract rules which the individual follows in his action, and the abstract overall order which is formed as a result of his responding, within the limits imposed upon him by those abstract rules, to the concrete particular circumstances which he encounters."

And in LLL III Hayek remarks:

"the work on it [SO] has helped me greatly to clear my mind on much that is very relevant to social theory. My conception of evolution, of a spontaneous order and of the methods and limits of our endeavours to explain complex phenomena have been formed largely in the course of the work on that book. As I was using the work I had done in my student days on theoretical psychology in forming my views on the methodology of the social science, so the working out of my earlier ideas on psychology with the help of what I had learnt in the social science helped me greatly in all my later scientific development." (p. 199, n. 26)

In a more piecemeal way, the influence of Hayek's cognitive psychology on his methodology and theory of society may be gathered from the following considerations (the list does not pretend to be complete):

The theorem of so that "any apparatus of classification must possess a structure of a higher degree of complexity than is possessed by the objects which it classifies (...)" (SO, p. 185) may be considered as the basis of all Hayek's "limited-knowledge" arguments, both in the field of philosophy of science and social philosophy. In the latter this argument takes the form that a spontaneous order is capable of performing more complex tasks (or more tasks) than one that is designed. This seems to bear a close parallel to the theory of the mind contained in SO, a parallel that is even closer in H's assertion that social institutions cannot be understood by man, the reason being that, by assumption, these institutions are capable of handling more complexity than the individual human mind. The counterpart of this type of argument in methodology can be found in Hayek's publications on complex systems, pattern predictions and explanations of the principle.

If human perception and knowledge functions as is described in so, then this is also true in the social domain, and theories of social science have to take this fact into account. This argument lies at the basis of Hayek's antiscientism and the distinction he makes between social and natural science. Combined with the thesis that knowledge of the external world always consists of a mental (re)construction, this leads directly to the distinstion that Hayek makes between natural and social science.

The conception of the human mind as a self-organizing system can be considered as ancestral to Hayek's idea that most social institutions are spontaneous 
orders, so prominent in his later work, and that this justifies the existence of social science. Cp. Hayek 1942-4, "Scientism and the study of society", p. $288:$

"If social phenomena showed no order except insofar as they were consciously designed, there would indeed be no room for theoretical sciences of society and there would be, as is often argued, only problems of psychology. It is only in so far as some sort of order arises as the result of individual action but without being designed by any individual that a problem is raised which demands a theoretical explanation."

The "rule-guided behaviour", which crops up in Hayek's publications in social philosophy in the $1960 \mathrm{~s}$ seems like a straightforward translation of the "relational" character of the mind as depicted in so.'

The argument that the genetic and the functional aspects of spontaneous orders cannot be separated, which we find in "Arten der Ordnung", (Freiburger Studien, 1967, p. 36) seems to be taken over directly from SO.

The evolution and "natural" selection of institutions finds its parallel in the description of the working of the mind, which eliminates classifications that are found to be inconsistent with new sensory stimuli.

In so there is an argument about the conservation of past knowledge:

"Sense experience (..) presupposes the existence of a sort of accumulated 'knowledge', of an acquired order of the sensory impulses based on their past co-occurrence; and this knowledge, although based on (pre-sensory) experience, can never be contradicted by sense experiences and will determine the forms of such experiences which are possible." (SO 8.8)

This foreshadows Hayek's argument that spontaneously evolved institutions contain the "wisdom of ages".

The parallels between So and Hayek's later theory of society suggest that Hayek's answer to the question whether society is mind-like would be affirmative. It is not. Hayek is very critical of attempts to apply "brain metaphors" to society. In "Notes on the Evolution of systems of Rules of Conduct" 1967) he says:

"Such spontaneous orders as those of societies, although they will often produce results similar to those which could be produced by the brain, are thus organized on principles different from those which govern the relations between a brain and the organism which it directs. Although the brain may be organized on principles similar to those on which a society is organized, society is not a brain and must not be represented as a sort of super-brain, because in it the acting parts and those between which the relations determining the structure are established are the same, and the ordering task is not deputized to any part in which a model is preformed." (p. 74$)$

What Hayek rejects in the mind-metaphor for society is a particular way of stating the problem. What he objects to in the passage quoted above is the the mind-metaphor of society as a device for trying to find a solution or clarification of the relation between a directing unit and the rest which is "executive". He has no objections to using the type of mechanism of so for modeling the evolution and functioning of social institutions. In that sense that Hayek thinks of society as mind-like.

A brief digression: Hayek's Sensory order and neural network theory

As a matter of history, so was one of the sources of inspiration of the theory of parallel distributed processes (PDP) or neural networks (NN). In The Brain as a Computer Pergamon Press 1961: 112), George observes: "The idea that the

7 Cp. also Miller 1979, p. 263.

8 The $1920 \mathrm{~ms}$. states this mental conservation principle in even stronger terms. 
human senses worked on a classification principle had previously been suggested by Hayek (1952), and Uttley was able to build a simple classification system in hardware." And again, on p. 319 the same author remarks: "It was Hayek (1952) who first suggested that the method of human perception was dependent upon a classification system. This suggestion was followed up by Uttley (1954, 1955) ..." And in 1958, Rosenblatt, in "The perceptron: a probabilistic model for information storage and organization in the brain" (in: Anderson \& Rosenfeld 1988, on p. 92) mentions Hayek's book, together with Donald Hebb's The Organization of Behaviour of 1949 as the most suggestive for later work on perceptrons.

There is an interesting parallel in the way in which Hayek's so influenced his later thought on social institutions, and the recent interest in applications of neural networks in the field of social science.

\title{
Cognitive psychology and methodology
}

In the above I have denied that there is an influence of Hayek's cognitive psychology on his early work in economics. Let me now qualify that statement. In sofar as there was an influence, it ran via Hayek's methodology. Or alternatively, there may have been a common idea underlying both part of Hayek's psychology and his methodology. It concerns the insistence on the theoretical character of all knowledge and the argument that knowledge can never be of particular observational "facts". This may explain why from his very earliest publications in economics he lays great stress on the importance of abstract theory as opposed to the gathering of statistical data. Hayek's stress on the importance of idealizing theories in the field of economics may be considered as a consistent methodological elaboration of the idea, expressed in SO, that all gathering of knowledge about the exernal world involves acts of classification on the part of the gatherer of knowledge, who must, of necessity, form "maps" and "models" of the world.

Theoretical unification, which is such a prominent item on Hayek's research agenda for economics, seems to find its precursor in the idea in so that the process by which the mind organizes perceptions and acquires knowledge culminates, if taken to its limits, in one unified classification of events in the world.

The compositive method and MI, so clearly applied in Hayek's work in economics and so strongly advocated in his earlier philosophy of science, can be reconstructed as deriving from the description of the working of the mind, which, by recombining sensory elements, approaches a true representation of the world ever more closely. ${ }^{9}$ The explanation of the principle, which starts to play a prominent part in Hayek's methodological work of the 1950's and '60's, is, again, a direct application of the theory of so that all the mind is capable of is knowledge of classes of events. Cp. SO, 8.57:

\begin{abstract}
"Explanation is always generic in the sense that it always refers to features that are common to all phenomena of a certain kind, and it can never explain everything to be observed on a particular set of events."
\end{abstract}

Conclusion

From the beginning of his work in economics, Hayek posed himself and elaborated a research programme consisting of two branches, a reductionist branch, and a subjectivist branch. As long as he was engaged in the reductionist part, he did not work out the subjectivism beyond the bare essentials necessary for his business cycle theory. For this he did not need cognitive psychology, his own or anyone else's, but he could rely on the distinction between economic reality as perceived and subjectively "charted" by individual agents, and the "fundamentals" of an economy. By the time when progress in the reductionist branch would have left Hayek with the time to elaborate the subjectivist branch, he had shifted his interest from an analysis of the acquisition of knowledge and the formation of expectations by individuals to the co-ordination of dispersed local knowledge of individuals. From the moment he resumed his work on psychology, the subjectivist part of the programme was both generalized into a theory of society and transformed

9 Related to this is Hayek's argument, in his methodological publications of the 1940's that social science does not explain, but merely classifies. This seems like a direct application of the description of the mental mechanism of $\mathrm{SO}$. 
so as to leave behind the MI that had characterized the reductionist part of the RP.

The influence of so made itself more and more felt in Hayek's work. This expressed itself in the emergence of the themes of evolution and spontaneous orders. Evolutionary arguments can already be found in Constitution of Liberty of 1960, Hayek's first systematic statement of a liberal social and political philosophy. But they are far less prominent than, for instance, in Law, Legislation and Liberty, which was published in 1973-79. For instance, in the former book, the evolutionary approach is still consistent with MI, while in the latter this is emphatically not the case. It looks as if it took a long time for the individualistic thrust of Hayek's RP in economics to lose momentum and to be superseded by the evolutionary drive that had become nested in Hayek's subjectivism. All this does not mean that there is no connection between some of the ideas that Hayek derived from his psychology and some of the methodological principles underlying his early work in economics. The connection may have been causal in the sense that his earlier work on psychology partly shaped his economic methodology, but it may also derive from a set of ideas underlying both Hayek's psychology and economics.

\section{Literature}

For books by Hayek the following abbreviations are used:

CL: The Constitution of Liberty (Hayek (1960))

CRS: The Counter-Revolution of Science (Hayek (1955a))

LLL: Law, Legislation and Liberty I, II en III (Hayek (1973), (1976),

MT: Monetary theory and the Trade Cycle (Hayek (1933))

PII: Profits, Interest and Investment (Hayek (1939))

PP: Prices and Production (Hayek (1931))

PTC: The Pure Theory of Capital (Hayek (1941))

RS: The Road to Serfdom (Hayek (1944))

SO: The Sensory Order (Hayek (1952a))

J. Birner (forthcoming), F.A. Hayeks Research Programme in Economics, Routledge

J. Birner \& R. van Zijp (eds.) 1994, Hayek, Co-ordination and Evolution; His legacy in philosophy, politics, economics and the history of ideas, Routledge

M. Bunge 1973, Model, Method and Matter, Reidel

B. Caldwell 1988, "Hayek's Transformation", HOPE

M. Colonna, H. Hagemann \& O. Hamouda (eds) 1995, The Economics of F.A. Hayek, Elgar

R.L. Cunningham (ed.) 1979, Liberty and the Rule of Law, Texas A\&M UP

F.A Hayek 1924, "Das Stabilisierungsproblem in Goldwährungsländern", Z.f.Volksw.u.Soz.pol.

F.A. Hayek 1925, "Die Währungspolitik der Vereinigten Staaten seit der Ueberwindung der Krise von 1920", I\&II, Z.f.Volksw.u.Soz.pol.

F.A. Hayek 1927, "Zur Problemstellung der Zinstheorie", Arch.Soz.w.Soz.pol., (the reference here is to the translation in McCloughry 1984)

F.A. Hayek (ed.) 1935, Collectivist Economic Planning, Kelley 1975

F.A. Hayek 1937, "Economics and Knowledge", in Hayek 1949

F.A. Hayek 1940, "Socialist Calculation III: The Competitive "Solution"", in Hayek 1949

F.A. Hayek 1941, The Pure Theory of Capital, Routledge \& Kegan Paul

F.A. Hayek 1943, "The Facts of the Social Sciences', in Hayek 1949

F.A. Hayek 1944, The Road to Serfdom, Routledge \& Kegan Paul

F.A. Hayek 1945, "Individualism True and False", in Hayek 1949

F.A. Hayek 1945a, "The Use of Knowledge in Society", in Hayek 1949

F.A. Hayek 1946, "The Meaning of Competition", in Hayek 1949

F.A. Hayek 1947, ""Free Enterprise" and Competitive Order", in Hayek 1949

F.A. Hayek 1949, Individualism and Economic Order, Routledge \& Kegan Paul

F.A. Hayek 1952, The Sensory Order, Chicago UP

F.A. Hayek 1955, The Counterrevolution of Science, The Free Press

F.A. Hayek 1955a, "Degrees of Explanation", in Hayek 1967

F.A. Hayek 1963, "Rules, Perception and Intelligibility", in Hayek 1967

F.A. Hayek 1963a, "Arten der Ordnung", in Hayek 1969a

F.A. Hayek 1964, "The Theory of Complex Phenomena", in Hayek 1967

F.A. Hayek 1965, "Kinds of Rationalism", in Hayek 1967

F.A. Hayek 1967, Studies in Philosophy, Politics and Economics, University of Chicago Press 
F.A. Hayek 1967a, "Notes on the Evolution of Systems of Rules of Conduct, in Hayek 1967

F.A Hayek 1968, "Competition as a Discovery Procedure", in Hayek 1978

F.A. Hayek 1969, "The Primacy of the Abstract", in Hayek 1978

F.A. Hayek 1969a, Freiburger Studien, Mohr, Tübingen

D.O. Hebb 1949, The Organization of Behaviour, Wiley

R. McCloughry (ed.) 1984, Money, Capital \& Fluctuations; Early Essays [by] F.A. Hayek, Routledge \& Kegan Paul

E.F. Miller 1979, "The Cognitive Basis of Hayek's Political Thought", in Cunningham 1979

K.R. Popper 1976, Unended Quest, Fontana

H.A. Simon 1968, The Sciences of the Artificial, MIT Press, 1975

R. de Vries 1994," The Place of Hayek's Theory of Mind and Perception $n$ the History of Philosophy and Psychology", in Birner \& Van Zijp 1994

W.B. Weimer \& D.S. Palermo (eds.) 1974, Cognition and the Symbolic Process, Erlbaum, Hillsdale, N.J. 